\title{
Perceived Motor Ability and Selection, 0ptimization, and Compensation: effects of age and institutionalization
}

\author{
Franisca Pimente - UniversidadedeÉvara, Évora, Potucgl \\ AntónioM Diniz - UnivesidadedeÉvara, Évara, Porturgl
}

\begin{abstract}
The authors examined the mediation effect of the perceived motor ability (PMA) on the direct "effects" of age (third vs. fourth age) and residential status (institutionalized vs. communitarians) on selection, optimization, and compensation (SO C) strategies. With a non-probabilistic sample of 107 elders (Mdn = 80 years) from urban areas, and controlled for cognitive impairment and depression, the authors analysed the structural component of the path model with latent constructs that represents those relationships. This was made only after the structural validity of the constructs had been assured. Constructs were operationalized through the PMA questionnaire and a 16-item version of the SOC questionnaire. O nly age had direct effects on the constructs: lower PMA and lower SOC of the elders in the fourth age. Authors also verified that the PMA mediation effect was partial.

Kegnards Elderly; Subjective functional health; SO C strategies; Structural equation modelling; Mediation effects.
\end{abstract}

Capacidade motora percebida e seleção, otimização e compensação: efeitos da idade e da institucionalização

\begin{abstract}
Resumo
Neste artigo examinou-se o "efeito" de mediação da capacidade motora percebida (CMP) nos efeitos diretos da idade (terceira vs. quarta idade) e do estatuto residencial (institucionalizados vs. comunitários) sobre estratégias de seleção, otimização e compensação (SO C). Com uma amostra não probabilística de 107 idosos (Mdn = 80 anos) residentes em meio urbano e controlados para demência e depressão, procedeu-se à análise da componente estrutural do modelo de trajetórias com construtos latentes que representa essas relações. Isto só foi feito depois de garantida a validade estrutural dos construtos, operacionalizados através do Questionário de CMP e de uma versão de 16 itens do Questionário SO C. Só a idade teve efeitos diretos sobre os construtos: menor CMP e menor SO C dos idosos na quarta idade. A CMP teve um efeito direto sobre as estratégias SOC: quanto menor CMP, menor SO C. Verificou-se, ainda, que o efeito de mediação da CMP foi parcial.

Palaurasdhave Idosos; Saúde funcional subjetiva; Estratégias SOC; Modelação de equações estruturais; Efeitos de mediação.
\end{abstract}

\section{Capacidad motora percibida y selección, optimización y compensación: efectos de la edad y de la institucionalización}

\begin{abstract}
Resumen
En este artículo se examinó el "efecto" de mediación de la capacidad motora percibida (CMP) en los efectos directos de la edad (tercera vs. cuarta edad) y del ámbito residencial (institucionalizados vs. comunitarios) sobre estrategias de selección, optimización y compensación (SO C). Con una muestra no probabilística de 107 ancianos (Mdn = 80 años) residentes en medio urbano y controlados para demencia y depresión, se procedió el análisis del componente estructural del modelo de trayectorias con constructos latentes que representan estas relaciones. Eso fue hecho después de garantizada la validez estructural de los constructos, operacionalizados a través del Cuestionario de CMP y de una versión de 16 ítems del Cuestionario SO C. Sólo la edad tuvo efectos directos sobre los constructos: menor CMP y menor SO C de los ancianos en la cuarta edad. La CMP tuvo un efecto directo sobre las estrategias SO C: cuanto menor CMP, menor SO C. Se verificó, aún, que el efecto de mediación de la CMP fue parcial.

Palabras dave Ancianos; Salud funcional subjetiva; Estrategias SO C; Modelación de ecuaciones estructurales; Efectos de mediación.
\end{abstract}

Due to the aging of populations, a growing concern has emerged regarding the increase of the level of autonomy and functionality of the elderly as forms to promote successful aging. Based on the importance that functional capabilities can have in assuring autonomy and daily life management, Baltes, Maas, Wilms, Borchelt and Little (1999) developed a model of everyday competence, which distinguishes two types of skills: a basic level (BaCo) necessary for survival, related to routine activities, such as self-care; and a more expanded level of competence (ExCo), conditioned by the previous, which refers to instrumental activities, leisure and social activities.

Although there is a tendency for the elderly over
85 years to show a lower level of activity and greater difficulty in their execution, some of them are able to maintain high levels of BaCo (Baltes \& cols., 1999). However, the authors report that aging per se is not responsible for the decline in $\mathrm{BaCo}$ and $\mathrm{ExCo}$, unlike health and psychosocial factors, which can have a significant impact in those skills.

\section{SubjetiveHelth, Fundional Status, and SubjetiveFundional} Helth

The $\mathrm{BaCo}$ levels required to the involvement in activities of daily living (ADL), such as bathing, dressing, walking, transferring, toileting and eating (Katz, Ford, Moskowitz, Jackson \& Jaffe, 1963; Walsh, 
K hatutsky \& Johnson, 2008), are rooted on the quality of elders' health.

\section{Subjetivehealth}

The assessment of elders' subjective health (SH) instead of their objective health $(\mathrm{OH})$ is recommendable, due to the progressive smaller relationship between $\mathrm{SH}$ and $\mathrm{OH}$ with the increase of age in the elderly (Borchelt, Gilbert, Horgas, \& Geiselmann, 1999; Cheng, 2004; Hoeymans, Feskens, Kromhout, \& Van den Bos, 1997). Moreover, health should be seen as a multifaceted concept, which diagnostic results from the assessment of both functional status (FS) and SH (Borchelt \& cols., 1999).

Most studies assess SH through the response to a single item such as "Would you say your health is ...?", reflecting the way each one evaluates their own health status and/ or considering their health perception when it is compared with other individuals of the same age (Cappeliez, Sèvre-Rosseau, Landreville, \& Préville, 2004; Pinquart, 2001; Sillén, Nilsson, Mansson, \& Nillson, 2005). This simple assessment technique allowed $\mathrm{SH}$ to be recognized as a good predictor of health status, morbidity and mortality (Sillén \& cols., 2005), as well as future institutionalization (Gutman, Stark, Donald, \& Beattie, 2001) and hospitalization (Menec \& Chipperfield, 2001).

\section{Fundianal Status}

Elders perceived their health as a result of their limitations in the activities they consider important, and accordingly to their ability to execute autonomously ADL (Paúl \& Fonseca, 1999). Elders' FS has an influence on their SH (Hoeymans \& cols., 1997; Pinquart, 2001).

Since the work of Katz and cols. (1963), the study of FS has been done mostly through the construct on disability, measured by standardized objective measures of physical performance as ADL indicators of impairment. Less typical than the measurement of functional limitations based on a hetero-assessment format, and more recently, the construct on perceived functional limitation (PFL), or perceived functional impairment, has proven to be useful in describing the pathway from chronic illness to disability (Lee \& Park, 2006): disability should be considered as a result of chronic illness. Moreover, examining elders' FS through a self-report format of administration (i.e., in a subjective way), as Lawton and Brody (1969) have done, is useful to health interventions: As strong predictor of disability (Guralnik \& Ferrucci, 2003), PFL can play a major role in designing preventive health interventions.

\section{SubjetiveFuntional Health}

The FS's research through molar indicators, such as ADL impairments, has produced interesting results. However, an alternative way of assessing FS is to use elementary indicators enrolled in ADL, as some of those belonging to the construct of functional health $(\mathrm{FH})$. The examination of $\mathrm{FH}$ is done by the heteroadministration of standardized objective measures of physical performance (Kunzmann, Little, \& Smith, 2000; Stheinhagen-Thiessen \& Borchelt, 1999). These techniques provide a more analytical description of FS, with indicators of sensory and motor abilities (e.g., vision, audition, balance and gait). However, by analogy with the constructs of $\mathrm{SH}$ and PFL, it might be advantageous to assess $\mathrm{FH}$ through a self-report format of administration, focusing on the elders' subjective functional health (SFH). The SFH construct can be definable, accordingly to its sensory and motor components, in terms of perceived sensory ability and perceived motor ability (PMA).

\section{Setetion, Optimization, and Compensation}

P. B. Baltes and M. M. Baltes (1990) developed a model of successful aging based on maximizing gains and minimizing losses through strategies of selection, optimization and compensation (SOC), which help facing the limitations and losses inherent to the aging process (Baltes, 1997; Freund \& Baltes, 1998, 2002).

There are two types of selection strategies: Elective selection (ES), based on the criteria of personal interest, and loss-based selection (LBS), which occurs in response to deficits or losses, such as those associated with aging. The optimization $(0)$ consists in the allocation and refinement of internal or external resources to achieve higher levels of functioning in the selected domains. The compensation strategies (C) result from the need to balance losses, through substitution processes, in order to maintain a level of functionality similar to the previously existent.

According to different studies, the use of SOC strategies is related to subjective indicators of successful development, life-management, and personality, at all ages (Baltes \& cols., 2005; Freund \& Baltes, 1998, 2002; Joop \& Smith, 2006), particularly the $\mathrm{O}$ and $\mathrm{C}$ strategies, as well as a composite index of all SOC strategies, rather than ES and LBS strategies (Freund \& Baltes, 1998, 2002). However, the very old adults show a decline in cognitive plasticity, and physical and biological constraints, which implies a decrease in the use of SOC-related behaviors (Baltes, 1997; Freund \& Baltes, 1998, 2002). Therefore, the transition between the third age and the fourth age (beginning around $75-80$ or $80-85$ years, depending on the population-base definition) must be taken into 
account among the elders (Baltes \& Smith, 2003). The World Health Organization (1999) established the age of 80 and above as the fourth age in European countries.

\section{Currett suady}

Based on the review of literature, we can presume an influence of the elders' age (third vs. fourth age) on their SFH, namely on PMA, and also on their SOC strategies. Meanwhile, we can also presume an influence of elders' PMA on their SOC strategies. Considering all these relationships we presume the existence of an indirect influence of elders' age on their SOC strategies mediated by their PMA.

With this study, we intend to assess the mediation effect of elders' PMA on the direct effects of age on SOC strategies. We examine if the direct effects of age and RS on SOC are reinforced by the indirect effect of these variables on SO C, represented by the direct effect of elders' age on their PMA, and the direct effect of elders' PMA on their SOC. In Figure 1, we present the conceptual diagram of the path model with latent constructs that represent this set of relationships. The figure also includes an identical set of relationships for the variable residential status (RS) because, besides the age effect on elders' disability and lack of autonomy, the increase of those factors can result in institutionalization, particularly in the fourth age (Wilmonth, 2002).

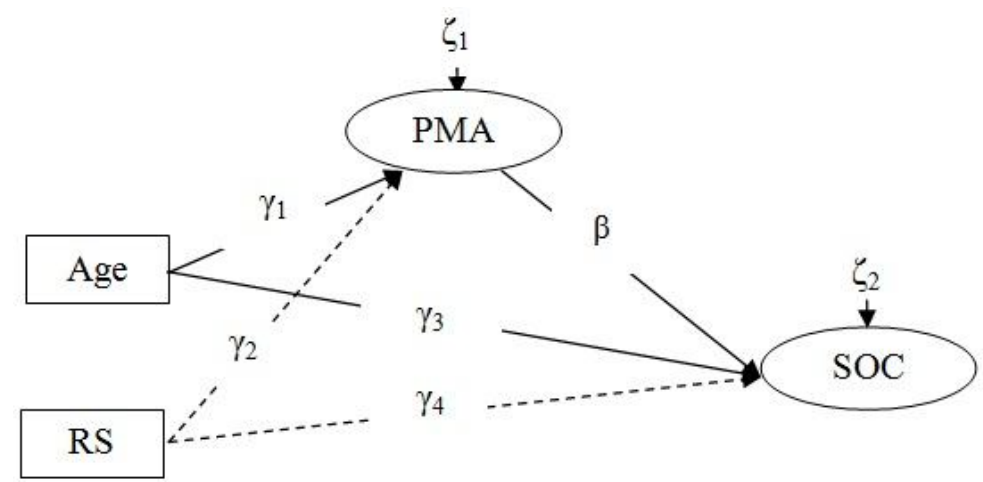

Figure 1. Path model with latent variables for Age and RS influence on PMA and SO C: Conceptual diagram

Note: Age (65-79 years vs. 80 or more years); RS = residential status (nursing houses vs. communitarians); PMA = perceived motor ability; SOC $=$ selection, optimization, and compensation. $\gamma_{\mathrm{i}}=$ direct effects of the observed predictors Age and RS on the latent constructs PMA and SOC; $\beta=$ direct effect between the latent constructs; $\gamma_{1} \times \beta$ and $\gamma_{2} \times \beta=$ indirect effects of Age and RS on SOC; $\zeta_{i}$ (random disturbances or structural residuals) $=$ amount of latent constructs' variance not accounted by predictors.

The elders' institutionalization involve both an adaptation to a set of new situations and a series of changes or losses in the resources that they previously had, with a potential negative impact in their adaptation (Baltes, Staudinger, \& Lindenberger, 1999).

Baltes, Maas e cols. (1999) verified that institutionalized elders are involved in fewer activities and show higher difficulty in their execution, rest more time, and spend less time in leisure activities. However, institutionalization does not seem to have, necessarily, a negative impact on the elderly (del Pino, 2003). Knowing that the context might, according to the existing conditions, promote the autonomy and better levels of functionality (Räty, Aromaa, \& Koponen, 2003), we should consider the nursing houses and residential care homes' diversity, and therefore the different conditions they offer (Duarte \& Paúl, 1994). The Baltes, Maas e cols. (1999) results, and these subsequent issues bounded the inclusion of the variable residential status (RS) in the model (Figure 1).

\section{Partiapants}

\section{Method}

A sample of 107 elderly Portuguese volunteers (age range $=65-96$ years; $\mathrm{M}=80$ ) was selected though non-probabilistic techniques in an urban environment. The majority of the participants were older than 79 years of age $(54.2 \%)$, women $(71 \%)$, and neither married nor living with a partner $(78.5 \%)$. Regarding education, most participants were illiterate $(27.1 \%)$ or had four or less years of schooling (52.3\%).

The sample was mainly composed by communitydwelling elders (68.2\%), and the remaining elders were living in nursing homes (with more than a year of institutionalization). Both community-dwelling and institutionalized elders were able to carry out ADL, and had a non-clinical situation regarding cognitive impairment, assessed though the Mini-Mental State Examination - MMMS (Guerreiro \& cols., 1994; Folstein, Folstein, \& McHugh, 1975), and depression, assessed though the 15-item G eriatric D epression Scale - GD S-15 (Sheikh \& Yesavage, 1986) with a 10/ 11 cut- 
off score (Tumas, Rodrigues, Farias, \& Crippa, 2008).

\section{Instruments}

MMSE

The Portuguese version of the MMSE (Guerreiro \& cols., 1994) was used for screening purposes. It has 11 questions related to five areas of cognitive function: Orientation (2 questions), registration (1 question), attention and calculation (1 question), recall (1 question), and language (6).

The range of the MMSE scores varies from zero to 30 points, and cut-off points for cognitive impairment should be based on educational levels, namely in the Portuguese version (Gerreiro \& cols., 1994), scores $\leq 27$ points for more than 11 years of schooling, scores $\leq 22$ points for one to 11 years of schooling, and scores $\leq 15$ points for illiteracy.

\section{GDS-15}

A Portuguese translation of the 15-item GDS (Diniz, 2007a), made in accordance with the International Test Commission's (2010; Hambleton, 2001) guidelines for translating and adapting tests (ITC Guidelines), was used for screening purposes. The items' statements indicate depression symptoms rated on a dichotomous response format: No $=0$, for the absence of the symptom; yes $=1$, for its presence. The punctuation of items number $1,5,7,11$, and 13 , needs to be recoded so that one indicates depression when answered negatively.

The range of the GD S-15' scores vary from zero to 15 points: Scores $>5$ points are suggestive of depression, and scores $\geq 10$ points are almost always indicative of depression. Tumas e cols. (2008) found, in Brazilian old adults with Parkinson's disease, that the GD S-15's cut-off score 8/ 9 was the best discriminator between depressed and non-depressed, but the cutscore 10/ 11 was the best for diagnostic purposes.

\section{PMA questionnaire}

The six items of the PMA questionnaire (Diniz, 2008) were used to assess elders' beliefs about their own basic motor abilities in ADL: Chewing; balance when bending down to pick up items from the floor; moving about (e.g., walking, climb up/ down steps); fine motor control (e.g., writing, sewing, doing/ undoing buttons, shaky hands); balance when standing still; strength in the hands (e.g., grabbing items, dropping items, cooking, doing the washing-up). The items' response format is presented in a 7-point Liket-type scale ( $0=$ extremely bad; $6=$ perfect), and their sequence of presentation was randomly organized.

\section{SOC questionnaire}

The first 16 items of the 48-item SOC questionnaire (Baltes, Baltes, Freund \& Lang, 1999; Freund \& Baltes, 2002) were used to assess participants' SOC life-management strategies. SOC items are dichotomous, each one with a target SOCrelated strategy statement and a distractor non-SOCrelated strategy, respectively describing the lifemanagement behaviour of two hypothetical persons. Facing the items' forced-choice format of response, respondents should decide which of the two statements represent the best match to their own behaviour: The choice of the SOC-related statement is the desirable answer. Items are sequentially organized in the following way: Item 1 as an indicator of ES, item 2 of $\mathrm{O}$, item 3 of LBS, item 4 of $\mathrm{C}$, and this sequence of SOC-related strategies is systematically repeated for the remaining items. SOC scores can be calculated for each one of SOC components (ES, O, LBS, and C) and also calculated as a unique composite score.

The first 12 items of the 16 used in the current study are also the first 12 in the SOC questionnaire. They belong to a shorter version (Baltes, Baltes \& cols., 1999; Freund \& Baltes, 1998), translated and adapted from English to be used with Portuguese elders, in accordance with the ITC Guidelines. This process is described in detail elsewhere (Amado, Diniz \& Martins, 2006), however, we highlight two issues: the need to create items for training purposes because of the difficulties to items' response in an administrationthrough-interview format, shown by the elders in a pilot study; and the need to create a parallel, more content simplified version of the items.

The confirmatory factor analysis (CFA) of the 12item Portuguese version, based on the data collected with a sample of 150 community-dwelling elders, revealed a single-factor structure composed by six items (ES, item 9; O, items 2 and 10; LBS, item 11; and C, items 4 and 12). Amado et al. (2006) pointed out a methodological-related explanation for that drastic reduction in the number of items: Potential nonrespondents in a self-report administration format, such as some of the participants in the study of the 12item SOC questionnaire in the Berlin Aging Study (Baltes, Baltes \& cols., 1999), can produce hazard responses in an administration-through-interview format, just to "please" the interviewer (social desirability bias), generating a non-desirable effect on items reliability. We can also say that this phenomenon is related with items' characteristics: Some are very long and have subtle differences between SOC and nonSO C-related strategies.

Based on this previous knowledge, a translation from English to Portuguese of the remaining 36 items 
of the 48-item SOC questionnaire was made (Diniz, 2007b), following the ITC Guidelines. Another translation of the 48-item SOC questionnaire was made in the context of the current study, but from German to Portuguese. We compared these two translations, focusing on the content of their first 16 items (the ones to be used in this study): An exception was made for the reliable six items previously mentioned (Amado \& cols., 2006). Special attention was given to the content of the other six items, and also to the new ones (items 13, 14, 15, and 16). Regarding the Portuguese elders' difficulties in the item response process, we anticipate a malfunctioning of some of the former six. Therefore those new items were included in the questionnaire with the purpose of increasing the number of items. In this 16-item version, we simplified the items' content, not only linguistically, but also trying to make it friendlier to an administration-through-interview format (Pimentel \& Diniz, 2010).

\section{Procedure}

Data collection

The elders, as well as their formal care-givers, were informed in advance of the objectives of the study, and provided us with an active consent to data collection. Convenience sampling was used to reach elders living in their homes, and intentional sampling was used to reach elders with other RS. Those living in nursing houses, and those living most days in senior day centers, were selected upon formal care-givers' information about their apparent non-clinical situation regarding cognitive impairment and depression.

The instruments were individually administered through an administration-through-interview format because of instrumental and ethical reasons presented in detail elsewhere (Diniz \& Amado, 2012).

The interview started with the collection of sociodemographic data based on a brief questionnaire. In a second phase, elders were screened, first for cognitive impairment, and after for depression: those with scores in MMSE indicative of a diagnostic of cognitive impairment $(n=60)$, and those with scores in GDS-15 indicative of a diagnostic of depression $(n=13)$ were excluded from our sample. The data collection procedure stopped after MMSE or GDS-15's administration when respective cut-off points were reached: this was done avoiding an interview's abrupt stop, and with subsequent information to the elders formal care-givers.

The protocol for data collection was concluded with the hetero administration of the PMA and the 16item SOC questionnaires through a contra-balanced sequence to avoid halo effects. Protocols with missing values $(n=28)$ were excluded from data analysis.

Data analysis

The IBM SPSS Statistics for Windows (version 19) was used for descriptive data analysis. The model presented in Figure 1 was tested using LISREL 8.53 (Jöreskog \& Sörbom, 2002).

The data collected for the test of the model is discrete, dichotomous for age (third age, $1=65-79$ years, vs. fourth age, $2=80$ or more years) and for RS ( 1 = nursing houses vs. $2=$ communitarians), and polytomous for the other variables. Categorical data requires, in LISREL 8, a specific type of parameterization (Jöreskog, 2005). On PRELIS 2 (Jöreskog \& Sörbom, 1996) the indicators' underlying latent continuous response cut by $\mathrm{m}$ - 1 threshold parameters ( $\mathrm{m}=$ number of response options) were used to produce the polychoric correlation matrix of those latent variables, along with their asymptotic covariance matrix. These matrices were used as input in LISREL.

Model estimation was done using the SIMPLIS command language (Jöreskog \& Sörbom, 1993) with the diagonally weighted least squares (DWLS) estimation technique, which adjustments for standard errors and model fit statistics to non-normality through the Satorra-Bentler scaled correction (Satorra \& Bentler, 1994). The DWLS robust estimation technique has a good performance in parameter estimation with small single-sample discrete data $(\mathrm{N}=100)$, even with complex models (20 indicators equally distributed by two factors) (Flora \& Curran, 2004).

The model of Figure 1 was tested following a two step approach (Anderson \& G erbing, 1988; Jöreskog \& Sörbom, 1993): Before the assessment of the unstandardized solution of model's structural relationships, we examined the standardized solution of the confirmatory factor analysis (CFA) of the measurement: First for both the PMA and SOC latent constructs' models, and after for the factor model with PMA and SOC constructs freely correlated. To assign the units of measurement of PMA and SOC constructs' the path for one of its items was fixed to one. We used item's standardized factor loadings $(\beta)$ to examine if they were adequate to represent their latent constructs. In this study, we used a $\beta$ cutoff value of .39/.40: This means that the minimum amount of variance accounted by respective latent construct $\left(\mathrm{R}^{2}\right)$ should be 16 .

It is important that latent constructs present acceptable convergent validity (CV), discriminant validity (DV), and reliability, to assure the structural validity of the measurement model (Anderson \& Gerbing, 1988). The DWLS standardized estimates of 
the measurement model allowed the examination of latent constructs' CV, DV, and composite reliability (CR) (Fornell \& Larcker, 1981). The CV was assessed through the indicators' average variance extracted (AVE), which should be at least .50. The DV was assessed by comparing the shared variance $\left(\varphi^{2}=\right.$ squared disattenuated correlation) between any two constructs and the AVE of each: The DV's values should be lower than the AVE's values. Construct's reliability is deemed acceptable for group comparisons when it reaches .80 (Nunnally \& Bernstein, 1994). When these criteria were not reached, the model was modified. Nevertheless, data-driven modifications of an initial model should be substantively justified to avoid capitalization on chance (MacCallum, Roznowski, \& Necowitz, 1992).

The $\chi^{2}$ statistic significance, the comparative fit index (CFI), and the root mean square error of approximation (RMSEA), were used to evaluate the goodness of fit (GOF) of the hypothesized model to empirical data. We used these last two GOF indices because DWLS' accuracy to produce $\chi^{2}$ values is only fully supported with a sample size larger than the one of our sample ( $\mathrm{N}=200$; Flora \& Curran, 2004): with a smaller sample like ours, the $\chi^{2}$ values have a propensity to be inflated, and consequently to be statistically significant. The $\chi^{2}$ is an absolute measure of the discrepancy between model and data: A level of probability lower than .05 for the $\chi^{2}$ indicates lack of fit (Jöreskog \& Sörbom, 1993). The CFI compares the model with its null counterpart, the independence model, indicating the amount of data co-variation that is reproduced by the model: it must be close or above .95 to show a good fit ( $\mathrm{Hu} \&$ Bentler, 1998). The RMSEA is a measure of the discrepancy per degree of freedom between model and data: a value close or below .06 indicate a good fit (Hu \& Bentler, 1998).
To assess whether each path in Figure 1 was statically significant, the DWLS unstandardized estimates were tested using critical ratios: $\mathrm{CR}$; $\mathrm{CR}=$ DWLS/ standard error (SE) of DWLS. Note that CR values are equivalent to z-test values when using unstandardized estimates and to ttest values when using standardized estimates. Usually, CR values greater than 1.96 were interpreted as significant at the $\mathrm{p}$ $<.05$ level (Kline, 2005), but because of our small sample size $(\mathrm{N}=107)$, we used a CR greater than 1.98 as significant at the $\mathrm{p}<.05$ level, and a CR greater than 1.66 as significant at the $\mathrm{p}<.10$ level. This last option is justifiable because DWLS' accuracy to produce standard errors is only fully supported with a larger sample size $(\mathrm{N}=200)$ (Flora \& Curran, 2004): With a smaller sample like ours, the values of SE are inflated, and consequently the magnitude of DWLS parameter estimates tend not to be significant.

The PMA's mediation effects were assessed through the Sobel z-test, which allows the comparison between unstandardized indirect (mediated) and direct effects: In order to do this test, it is mandatory that both of the paths of the indirect effect, and also the indirect effect itself, be significant (Iacobucci, Saldanha, \& Deng, 2007).

\section{Results}

\section{Structural V alidityof theMeasurement Modd PMA model}

According to previously described cutoff values for GOF statistics, the results of the CFA showed that the 6-item PMA's single-factor model was well-fitted to the pooled sample data $\left(\chi^{2}=13.25, \mathrm{df}=9, \mathrm{p}=\mathrm{ns}\right.$ CFI $=1.00 ;$ RMSEA $=.07)$, and that this latent construct presented good CV (AVE) and CR (Table 1).

Table 1. PMA model: DWLS standardized estimates, MVE, and CR

\begin{tabular}{lcc}
\hline Item & $\beta$ & $\mathrm{R}^{2}$ \\
\hline Chewing & .62 & .38 \\
Balance when bending down to pick up items from the floor & .76 & .57 \\
Fine motor control & .76 & .58 \\
Hand's extremities motor skills & .65 & .43 \\
Balance when standing still & .82 & .68 \\
Strength in the hands & .67 & .45 \\
AVE & \multicolumn{2}{c}{.51} \\
FC & \multicolumn{2}{c}{.86} \\
\hline
\end{tabular}

Note: $\mathrm{AVE}=$ average variance extracted; $\mathrm{CR}=$ composite reliability. $\beta$ = standardized factor loading (with $\mathrm{p}<.001$ ); $\mathrm{R}^{2}$ (communality) $=1$ $\varepsilon$ (standardized residual).

\section{SOC model}

The CFA' solution of the 16-item SOC's four factor oblique model (ES, O, LSB, and $\mathrm{C}$ latent constructs) was not admissible to analysis because the covariance matrix of independent variables (i.e., latent constructs) was not positively definite: their 
disattenuated correlations were anomalously high (ESLSB, $\varphi=1.98$; O-C, $\varphi=1.05$; ES-C, $\varphi=-1.83$; ES-O $\varphi$ $=-2.01)$, with the exception of two respecting LSB $(\varphi$ $=-.78$ with $\mathrm{O}$, and $\varphi=-.77$ with $\mathrm{C}$ ). This result indicates item's multi-colinearity and therefore the necessity to collapse them in a single latent construct, SOC.

The results of the CFA of the 16-item SOC's single-factor model showed that the model was well fitted to the pooled sample data $\left(\chi^{2}=110.30, \mathrm{df}=104\right.$, $\mathrm{p}=\mathrm{ns}$ CFI $=1.00$; RMSEA $=.02)$. However, the estimates of the items 5 (ES), 8 (C), and 13 (ES), indicated that they were not good enough to represent the latent construct $\left(\mathrm{R}^{2}<.16\right)$ (Table 2, M1), and, therefore, they were excluded from the model.

Table 2. SO C model: DWLS standardized estimates, MVE, and CR

\begin{tabular}{|c|c|c|c|c|c|c|}
\hline \multirow{2}{*}{ Item (SO C strategy) } & \multicolumn{2}{|c|}{ M1 } & \multicolumn{2}{|c|}{ M2 } & \multicolumn{2}{|c|}{ M3 } \\
\hline & $\beta$ & $\mathrm{R}^{2}$ & $\beta$ & $\mathrm{R}^{2}$ & $\beta$ & $\mathrm{R}^{2}$ \\
\hline 1 (ES) & .51 & .26 & .51 & .26 & - & - \\
\hline 5 (ES) & .11 & .01 & - & - & - & - \\
\hline 9 (ES) & -.47 & .22 & -.48 & .23 & .50 & .25 \\
\hline 13 (ES) & .01 & .00 & - & 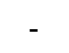 & - & \\
\hline $2(0)$ & -.56 & .31 & -.57 & .32 & .59 & .35 \\
\hline $6(0)$ & -.71 & .50 & -.71 & .50 & .71 & .51 \\
\hline $10(0)$ & -.65 & .43 & -.66 & .43 & .68 & .46 \\
\hline $14(0)$ & -.80 & .65 & -.80 & .64 & .78 & .61 \\
\hline 3 (LBS) & .49 & .24 & .48 & .23 & - & - \\
\hline 7 (LSB) & -.46 & .21 & -.46 & .21 & .47 & .22 \\
\hline 11 (LSB) & -.47 & .22 & -.48 & .23 & .48 & .23 \\
\hline 15 (LSB) & .52 & .27 & .50 & .25 & - & - \\
\hline $4(\mathrm{C})$ & -.50 & .25 & -.50 & .25 & .53 & .28 \\
\hline 8 (C) & .10 & .01 & - & - & - & - \\
\hline $12(\mathrm{C})$ & -.70 & .49 & -.70 & .49 & .74 & .54 \\
\hline 16 (C) & -.88 & .77 & -.88 & .77 & .86 & .74 \\
\hline $\begin{array}{l}\text { AVE } \\
\text { CR }\end{array}$ & & & & & & \\
\hline
\end{tabular}

Nđe ES = Elective Selection, $0=0$ ptimization; LBS $=$ Loss-Based Selection; $\mathrm{C}=$ Compensation. $\mathrm{AVE}=$ average variance extracted; $\mathrm{CR}=$ composite reliability. $\beta=$ standardized factor loading (with $\mathrm{p}<.001$ in Model 3); $\mathrm{R}^{2}$ (communality) $=1-\varepsilon$ (standardized residual).

The model without these items was well fitted $\left(\chi^{2}\right.$ $=80.39, \mathrm{df}=65, \mathrm{p}=\mathrm{ns}$ CFI $=1.00$; RMSEA $=.05)$. The items were adequate to represent the latent construct, but the items 1 (ES), 3 (LBS), and 15 (LSB), showed a pattern of relationship (positive) opposite from the other items (negative) (Table 2, M2), and, therefore, they were excluded from the model.

The CFA of the SOC's single-factor model with the remaining 10 items showed that it was well-fitted $\left(\chi^{2}=41.75, \mathrm{df}=35, \mathrm{p}=\mathrm{ns}\right.$ CFI $=1.00$; RMSEA $=$ $.04)$, and that this latent construct presented good CV (AVE) and CR (Table 2, M3).

It should be mentioned that five of the items excluded in this process were indicators of selectionrelated strategies (ES and LBS), and one belongs to Crelated strategies.
PMA and SOC oblique model

The CFA of the PMA and SOC's two factor oblique model showed that it was well-fitted $\left(\chi^{2}=\right.$ 120.82.75, $\mathrm{df}=103, \mathrm{p}=\mathrm{ns} \mathrm{CFI}=1.00$; RMSEA $=$ $.04)$, and that the shared variance between the two latent constructs $\left(\varphi^{2}=.14\right)$ was minor that the AVE of each of them, indicating a model's good DV.

\section{Structural Modd}

The test of the model presented in Figure 1 showed that it was well-fitted to the pooled sample data, as can be seen through the GOF statistics presented in the caption of Figure 2. For simplicity purposes, only the structural relationships are presented in the figure. 


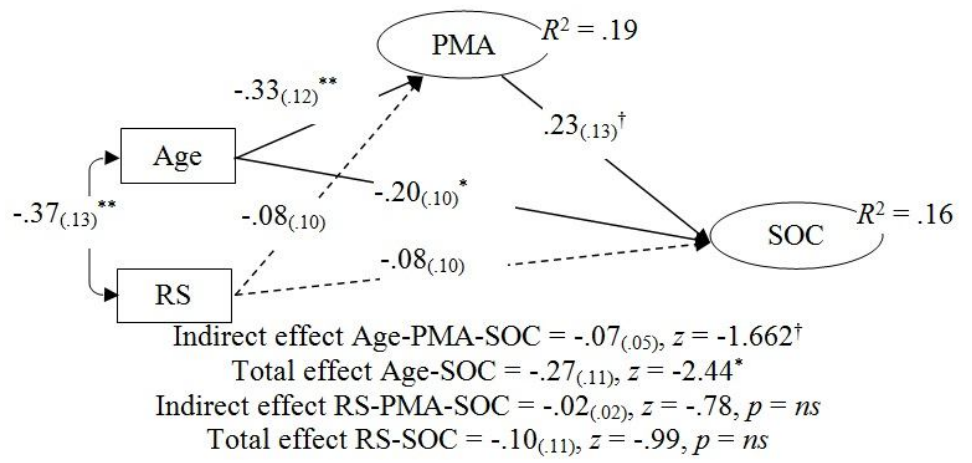

Figure 2. Path model with latent variables for Age and RS influence on PMA and SOC: Unstandardized DWLS estimates for structural relationships

Note: Age $(1=65-79$ years vs. $2=80$ or more years $)$ RS $(1=$ nursing houses vs. $2=$ communitarians $)$. Goodness of fit statistics: $\mathrm{SB} \chi^{2}=143.22, \mathrm{df}=131, \mathrm{p}=\mathrm{ns} \mathrm{CFI}=1.00$; RMSEA $=.03$. Standard errors in parenthesis; $\mathrm{R}^{2}$ (coefficient of determination) $=$ amount of the latent constructs' variance accounted by predictor(s). See Figure 1 for other abbreviations.

tp $<.10, * \mathrm{p}<.05, * * \mathrm{p}<.01$.

In Figure 2, we can see through the CR of the DWLS estimates for the model's unstandardized solution that only age had direct effects that were statistically significant on the latent constructs: lower PMA and lower SOC of the elders in the fourth age. Subsequently, the amount of the latent constructs' variance accounted by predictor(s) $\left(\mathrm{R}^{2}\right)$ was mainly a function of age differences.

We can also see in Figure 2 that the direct effect of PMA on SOC was marginally significant: Higher PMA, higher SOC. Meanwhile, the magnitude of the indirect (mediated) effect of age on SOC was marginally significant, contributing less than the direct effect to the total effect of age on SOC. However, the apparent difference in magnitude and in significance between indirect and direct effects was denied by a non-significant Sobel z-test's result $(\mathrm{z}=1.15, \mathrm{p}=\mathrm{ns})$ : the PMA mediation effect was partial, with comparable sizes between indirect and direct effects, in the presence of the direct (cf. Iacobucci \& cols., 2007).

\section{Discussion}

This study examined, through structural equation modelling, the mediation effect of PMA on the direct effects of age (third vs. fourth age) and RS (institutionalized vs. communitarians) on SOC strategies.

Concerning the PMA latent construct, it was well fitted to the pooled sample data, and showed a good $\mathrm{CV}$ and $\mathrm{CR}$. Concerning the SOC latent construct, it was also well fitted to the pooled sample data, and also showed a good CV and CR. However, the anomalous correlations verified between most of the various $\mathrm{SOC}$ related strategies (ES, O, LBS, and C) pointed out to a single-factor model to represent the construct, and that it was essentially characterized by $\mathrm{O}$ and $\mathrm{C}$ items.
The verified data-driven reduction of the number of items (from 16 to 10), and their aggregation in a single latent construct ( $\mathrm{SOC}$ ), must be substantively justified to avoid capitalization on chance (MacCallum \& cols., 1992). Therefore, it should be noted that similar results were found in another study with Portuguese elders (Amado \& cols., 2006). In addition, both of these results might be related to the fact that the scores of $\mathrm{O}, \mathrm{C}$, and the composite score of the SOC questionnaire, were the most related factors to indicators of successful aging in Freund and Baltes' (1998) study. It should also be considered that the participants of this study had a low level of literacy, compared to other studies of the SOC questionnaire (Freund \& Baltes, 1998, 2002). These participants' characteristic might have contributed to improve their difficulty in understanding and answering to some items of the questionnaire. Moreover, in order to overcome limitations of $\mathrm{FH}$ problems and/ or of illiteracy, our option was to administrate the instruments through an interview format, which may have hampered the response task even more. In this process, the elderly would have to choose between a response SOC or not SOC, which implies some attention and memorization capacity about differences, which sometimes are subtle. On the other hand, in case of doubt, people could feel more inhibited to ask to read the items repeatedly, unlike the self-report format, in which people can re-read the items as many times as necessary. This may result in random responses, just in order to please the interviewer (Amado \& cols., 2006).

The test of the path model with the PMA and SOC latent constructs showed that only age had direct effects on them: there was a lower PMA and a lower $\mathrm{SOC}$ in the elders in the fourth age. These results can be explained by the fact that the fourth age is characterized by considerable losses at cognitive level, 
increased chronic stress syndrome, dementia and high levels of fragility, vulnerability, and dysfunctional multimorbidity (Baltes \& Smith, 2003). The literature shows that in the fourth age, the decrease in FS and the increase of diseases may have a negative impact on $\mathrm{SH}$ (Hoyemans \& cols. 1997; Pinquart, 2001), and, we say, on SFH, or more specifically on PMA. Regarding SOC strategies, we found what other studies have pointed out a decrease in the use of SO C-related behaviours in older aged persons (Freund \& Baltes, 1998, 2002). In the fourth age, the decrease in plasticity, and the increased losses, cause a reduction in resources and, therefore, the elderly are not able to compensate losses with these mechanisms of life-management (Baltes, 1997).

On the other hand, RS had no effect on both PMA and SOC, reinforcing the idea that the institutional setting, by itself, does not always have a negative impact in the elderly (del Pino, 2003). Furthermore, it is important to mention that the majority of the community-dwelling elders that participate in the study were users of senior day centers, so they have daily contact with institutional dynamics, which may be similar to those found in nursing houses. This fact might have reduced the differences between the two groups regarding activities and daily experiences.

This study also shows that PMA had a direct effect on SO C strategies: the lower the PMA, the lower the SOC. Moreover, it was verified that the PMA mediation effect was partial, with comparable sizes between indirect and direct effects, in the presence of the direct. This phenomenon reinforces the importance of considering subjective factors in the study of aging and the important role they might have in maintaining a successful aging, particularly in the use of SOC strategies.

Finally, it should be noted that the models in appreciation were assessed in terms of their interpolative predictive accuracy (i.e., within the prediction domain of observed data) (Forster, 2002). Therefore, there are limits to the extrapolation of this study's results, and even more to its generalization, due to sampling procedure, to sample characteristics, and to the specific data collection procedure.

\section{References}

Amado, N., Diniz, A. M., \& Martins, M. (2006). Estudo preliminar da adaptação portuguesa para idosos do Selection, Optimization and Compensation Questionnaire (Short Version) [A preliminary study of the Selection, Optimization and Compensation Questionnaire's (Short
Version) Portuguese adaptation for elders]. Em C. Machado, L. S. Almeida, M. A. Guisande, M. Gonçalves \& V. Ramalho (Orgs.), Adas da XI Confê̂nia Intenacional de Avaliação Psicoógica: Fomas e Contextos (pp. 215-222). Braga: Psiquilíbrios.

Anderson, J. C., \& Gerbing, D. W. (1988). Structural equation modeling in practice: a review and recommended two step approach. Psydhdojal Bullein, 103, 411-423. doi:10.1037/ 00332909.103.3.411

Baltes, P. B. (1997). On the incomplete architecture of human ontogenesis: selection, optimization, and compensation as foundations of developmental theory. Ammican Psychdogist, 52, 366-380. doi: 10.1037/ 0003-066X .52.4.366.

Baltes, P. B., \& Baltes, M. M. (1990). Psychological perspectives on successful aging: the model of selective optimization with compensation. Em P. B. Baltes \& M. M. Baltes (Eds.), Surcesful aging pespetives from the behavioral saienes (pp. 1-34). Cambridge, MA: Cambridge University Press.

Baltes, P. B., Baltes, M. M., Freund, A. M., \& Lang, F. (1999). The mestement of setion, qptimization and compensation (sod) by self repart: technical repart 1999. Berlin: Max-Planck-Institut für Bildungsforschung.

Baltes, P. B., D elius, J., Krampe, R. T., Kreppner, K., Kunzmann, U., Li, S. C., \& Smith, J. (2005). Center for lifespan psyddogy (Research Report 2003-2004). Berlin: Max Planck Institute for Human D evelopment.

Baltes, M. M., Maas, I., Wilms, H., Borchelt, M., \& Little, T. D . (1999). Everyday competence in old and very old age: theoretical considerations and empirical findings. Em P. B. Baltes \& K. U. Mayer (Eds), The Belin agingsudy: aging from 70 to 100 (pp. 384-402). Cambridge, UK: Cambridge University Press.

Baltes, P. B., \& Smith, J. (2003). New frontiers in the future of aging: from successful aging of the young old to the dilemmas of fourth age. Gecontdogy, 49, 123-135. doi: 10.1159/ 000067946

Baltes, P. B., Staudinger, U. M., \& Lindenberger, U. (1999). Lifespan psychology: theory and application to intellectual functioning. Annual Review of Psychdogy, 50, 471-507. doi: 10.1146/ annurev.psych.50.1.471

Borchelt, M., Gilbert, R., Horgas, A. L., \& G eiselmann, B. (1999). On the significance of morbidity and 
disabillty in old age. Em г. ь. Baltes $\& \mathrm{~K}$. U. Mayer (Eds.), TheBelin ag்ing surdy: aging from 70 to 100 (pp. 403-429). Cambridge, UK: Cambridge University Press.

Cappeliez, P., Sèvre-Rosseau, S., Landreville, P., \& Préville, M. (2004). Physical health, subjective health, and psychological distress in older adults: reciprocal relationships concurrently and over time. Aging Intemational, 29, 247-266. doi: 10.1007/ s12126-996-1001-y

Cheng, S. (2004). Age and subjective well-being revisited: a discrepancy perspective. Psydhology and Aging 19, 409-415. doi: 10.1037/ 08827974.19.3.409

del Pino, A. C. S. (2003). Calidad de vida en la atención al mayor [Quality of life in the elderly caregiving]. Revista Multidisciplinar deGeontdogá, 13, 188-192.

Diniz, A. M. (2007a). Escala deDeqresão Geiátrica: vesão reduzida [G eriatric D epression Scale: Short Form]. Lisbon: Author.

Diniz, A. M. (2007b). QuestianániodeSeleçãa Optimização e Compensação [Selection, Optimization, and Compensation Questionnaire]. Lisbon: Author.

Diniz, A. M. (2008). Quectionánio de Capadidade Motora Pecedida [Perceived Motor A bility Questionnaire]. Lisbon: Author.

Diniz, A. M., \& Amado, N. (2012). Procedures for surcessful data colletion through psychoogical tests in the ddaly. Manuscrito submetido para publicação.

Duarte, M., \& Paúl, C. (1994). Avaliação do ambiente institucional-público e privado: estudo comportamental dos idosos [Evaluation of the public and private institutional environment: Behavioral study of the elderly]. Rerista Transdisapinar deGerantdoga, 1, 17-29.

Flora, D. B., \& Curran, P. J. (2004). An empirical evaluation of alternative methods of estimation for confirmatory factor analysis with ordinal data. Psychdog்al Methoos, 9, 466-491. doi:10.1037/ 1082989X .9.4.466

Folstein M. F., Folstein S. E., \& McHugh, P. A. (1975). Mini-Mental State: a practical method for grading the cognitive state of patients for clinician. Jamal of Psychiatric Reserch, 12, 189-198. doi: 10.1016/ 0022-3956(75)90026-6

Fornell, C., \& Larcker, D. F. (1981). Evaluating structural equation models with unobservable variables and measurement error. Joumal of Markeing Rescerch, 18, 39-50.
d01:1U.23U// 3151312

Forster, M. R. (2002). Predictive accuracy as an achievable goal of science. Philosphy of Sience, 69, S124-S134. doi: 10.1086/ 341840

Freund, A. M., \& Baltes, P. B. (1998). Selection, optimization, and compensation as strategies of life-management: correlations with subjective indicator of successful aging. Psychdogy and Aging 13, 531-543. doi: 10.1037/ / 0882-7974.13.4.531

Freund, A. M., \& Baltes, P. B. (2002). Lifemanagement strategies of selection, optimization, and compensation: measurement by self-report and construct validity. Jamal of Pesonality and Social Psychdogy, 82, 642-662. doi: 10.1037/ 00223514.82.4.642

Guerreiro, M., Silva, A. P., Botelho, M. A., Leitão, O ., Castro-Caldas, A., \& G arcia, C. (1994). Adaptação à população portuguesa da tradução do "Mini Mental State Examination" (MMSE) [Adaptation of the Mini Mental State Examination's translation to the Portuguese population]. Revista Patuguesa deNerdoga, 1, 9-10.

Guralnik, J. M., \& Ferrucci, I. (2003). Assessing the building blocks of function. Utilizing measures of functional limitation. Amercan Jamal of Preventive Meediane 25 (3, suppl. 2), 112-121. doi: 10.1016/ S0749-3797(03)00174-0

Gutman, G. M., Stark, A., D onald, A., \& Beattie, B. L. (2001). Contribution of self-reported health ratings to predicting frailty, institutionalization, and death over a 5-year period. Intemational Psidogriatriss 13, 223-231. doi: 10.1017/ S1041610202008165

Hambleton, R. K. (2001). The next generation of the ITC test translation and adaptation guidelines. European Joumal of Psydulogical Assessmet, 17, 164172. doi: 10.1027/ / 1015-5759.17.3.164

Hoeymans, N., Feskens, E., Kromhout, D., \& Van den Bos, G. (1997). Ageing in the relationship between functional status and self-rated health in elderly men. Scoial Saiene and Meidine, 45, 15271536. doi: 10.1016/ S0277-9536(97)00089-0

$\mathrm{Hu}$ L., \& Bentler, P. M. (1998). Fit indices in covariance structure modeling: sensitivity to underparametrized model misspecification. Psychdogical Methoos, 3, 424-453. doi:10.1037/ 1082989X.3.4.424

Iacobucci, D., Saldanha, N., \& Deng, X. (2007). A meditation on mediation: Evidence that structural equations models perform better than regressions. 
Jaumal of Consumer Psydhogy, 17, 139-153. 10.1016/ S1057-7408(07)70020-7

International Test Commission (2010). Intemational Tet Commission Guiddines for Trandating and Adapting Tests Recuperado: http:/ / www.intestcom.org

Jopp, D., \& Smith, J. (2006). Resources and lifemanagement strategies as determinants of successful aging: on the protective effect of selection, optimization, and compensation. Psychdoy and Aging 21, 253-265. doi: 10.1037/ 0882-7974.21.2.253

Jöreskog, K. G. (2005). Structural equation moding with adimal vanables using LISREL. Disponível: http:// www.ssicentral.com/ lisrel/ techdocs

Jöreskog, K. G., \& Sörbom, D. (1993) LISREL 8: structural equation moddingwith theSIMPLIS command langrage Chicago: Scientific Software International.

Jöreskog, K. G., \& Sörbom, D. (1996). PRELIS 2: usa's referere gride Chicago: Scientific Software International.

Jöreskog, K. G., \& Sörbom, D. (2002). LISREL 8.53 for Windous Chicago: Scientific Software International.

Katz, S., Ford, A.B., Moskowitz, R.W., Jackson, B. A., $\&$ Jaffe, M. W. (1963). Studies of illness in the aged. The Index of ADL: a standardized measure of biological and psychosocial function. Jamal of the Ameican Medical Assoiation 185, 914-919. doi:10.1001/ jama.1963.03060120024016

Kline, R. B. (2005). Piniples and pradice of stuctural equation modding (2. ed.). New York: Guilford Press.

Kunzmann, U., Little, T. D ., \& Smith, J. (2000). Is agerelated stability of subjective well-being a paradox? Cross-sectional and longitudinal evidence from the Berlin aging study. Psychdogy and Aging 15, 511-526. doi: 10.1037/ 08827974.15.3.511.

Lawton M. P., \& Brody E. M. (1969). Assessment of older people: self-maintaining and instrumental activities of daily living. Geontdogist, 9, 179-186. doi:10.1093/geront/ 9.3_Part_1.179

Lee, Y., \& Park, K. (2006). Health practices that predict recovery from functional limitations in older adults. Ameican Jamal Preentive Medione, 31, 2531. doi:10.1016/ j.amepre.2006.03.018

MacCallum, R. C., Roznowski, M., \& Necowitz, L. B. (1992). Model modification in covariance structure analysis: the problem of capitalization on chance. Psychdogical Bulldin, 111, 490-504. doi:10.1037/ 0033-2909.111.3.490

Menec, V. H., \& Chipperfield, J. G. (2001). A prospective analysis of the relation between selfrated health and health care use among elderly Canadians. Canadan Jamal on Ag̈ng 20, 293-306. doi:

http:/ / dx.doi.org/ 10.1017/ S0714980800012794

Nunnally, J. C., \& Bernstein, I. H. (1994). Psychomenic thery(3. ed.). New York: McG raw-Hill.

Paúl, C., \& Fonseca, A. M. (1999). A saúde e a qualidade de vida dos idosos [Health and quality of life in the elderly]. Psicdoja, Eduracão eCultura, 3, 345-362.

Pimentel, A. F., \& Diniz, A. M. (2010). Questionánio de Sdecçãa Optimizacão eCompensarãão (vesãode 16 itens) [Selection, Optimization, and Compensation Questionnaire (16-items version)]. Lisbon: Author.

Pinquart, M. (2001). Correlates of subjective health in older adults: a meta-analysis. Psychdogy and Aging 16, 414-426. doi: 10.1037/ / 0882-7974.16.3.414

Räty, S., Aromaa, A., \& Koponen, P. (2003). Measurenent of physical functioning in comprehensive national heglth surves - ICF as a framescok (Report). Helsinki: National Public Health Institute, KTL. Recuperado:

http:/ / www.ec.europa.eu/ health/ph projects/ 20 $00 /$ monitoring/ fp monitoring 2000 annexe15 0 4 en.pdf

Satorra, A., \& Bentler, P. M. (1994). Corrections to test statistics and standard errors in covariance structure analysis. Em A. von Eye \& C. C. Clogg (Eds.), Latent vaniable amalysis (pp. 399-419). Thousand Oaks, CA: SAGE.

Sheikh, J. I., \& Yesavage, J. A. (1986). Geriatric Depression Scale (GDS): recent evidence and development of a shorter version. Clinical Gerontdogist, 5, 165-172. doi: 10.1300/ J018v05n01_09

Sillén, U., Nilsson, J., Mansson, N., \& Nillson, P. (2005). Self-rated health in relation to age and gender: influence on mortality risk in the Mälmo preventive project. Scandinavian Jamal of Public Health 183-189. 33, doi: 10.1080/ 14034940410019235

Stheinhagen-Thiessen, E., \& Borchelt, M. (1999). Morbidity, and functional limitations in very old age. Em P. B. Baltes \& K. U. Mayer (Eds.), The 
Belin Ag̈ng Study: Ag்ng from 70 to 100 (pp. 131166). Cambridge, UK: Cambridge University Press.

Tumas, V., Rodrigues, G. G. R., Farias, T. L. A., \& Crippa, J. A. S. (2008). The accuracy of diagnosis of major depression in patients with Parkinson's disease: a comparative study among the UPDRS, the Geriatric Depression Scale and the Beck Depression Inventory. Arquivos deNerrqpiquiatria, 66, 152-156.

Walsh, E. G., Khatutsky, G., \& Johnson, L. (2008). Functional impairment levels in PACE enrolees. Health CareFinaningReriew, 29, 81-88.

Wilmonth, J. (2002). Arranjos de vida de idosos nos
Estados Unidos [Older adult living arrangements in the United States]. Soadogas 7, 136-155. doi: 10.1590/ S1517-45222002000100006

World Health O rganization (1999). Helth21: Thehelth for all poligy framencok for theWHO Europeen Region (European Health for All Series, No. 6). Copenhagen: WHO Regional Office for Europe. Recuperado:

http:/ / www.euro.who.int/ data/ assets/ pdf file/ 0 010/ 98398/ wa540ga199heeng.pdf

Reedidbem08/ 03/ 2012

Reformuladbem28/06/2012

Aprovadbem11/ 07/ 2012

Nota dos autores:

This study is included in the research project of the first author's doctoral dissertation, supervised by the second author, at the Department of Psychology of the University of Évora, Évora, Portugal.

Sobre os autores:

Ana Francisca Pimentel is graduated in psychology by the Faculty of Psychology and Educational Sciences, University of Porto, and is a doctoral student in the Department of Psychology, University of Évora, with a dissertation focused on the successful aging of community-dwelling and institutionalized elders. She is a project coordinator in the Piaget Agency for Development (APDES), Porto, domain of health promotion, namely with institutionalized elders.

António M. Diniz is an assistant professor in the Department of Psychology, University of Évora, where he teaches research methods. His research interests include quantitative and qualitative data analysis applied to psychological assessment and psychosocial aspects of aging.

Contato com os autores:

Departamento de Psicologia, Universidade de Évora

Colégio Pedro da Fonseca, Parque Industrial e Tecnológico de Évora, Rua da Barba Rala, 7000 Évora, Portugal. 